\title{
NSUF Melt Wire Evaluations for BSU-8242 and GE Hitachi-10393 Irradiation Experiments
}

Kurt L. Davis

Lance A. Hone

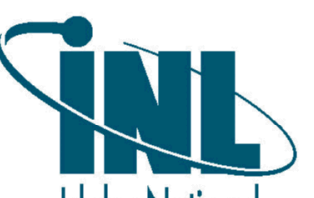

Idaho National

Laboratory 


\section{DISCLAIMER}

This information was prepared as an account of work sponsored by an agency of the U.S. Government. Neither the U.S. Government nor any agency thereof, nor any of their employees, makes any warranty, expressed or implied, or assumes any legal liability or responsibility for the accuracy, completeness, or usefulness, of any information, apparatus, product, or process disclosed, or represents that its use would not infringe privately owned rights. References herein to any specific commercial product, process, or service by trade name, trade mark, manufacturer, or otherwise, does not necessarily constitute or imply its endorsement, recommendation, or favoring by the U.S. Government or any agency thereof. The views and opinions of authors expressed herein do not necessarily state or reflect those of the U.S. Government or any agency thereof. 
INL EXT-20-

Revision 0

\section{NSUF Melt Wire Evaluations for BSU-8242 and GE Hitachi-10393 Irradiation Experiments}

Kurt L. Davis

Lance A. Hone

April 2020

Idaho National Laboratory

Idaho Falls, Idaho 83415

http://www.inl.gov

Prepared for the U.S. Department of Energy Office of Nuclear Energy Under DOE Idaho Operations Office

Contract DE-AC07-05ID14517 
Page intentionally left blank 


\begin{abstract}
The Nuclear Science User Facilities (NSUF) is the United States Department of Energy Office of Nuclear Energy's only designated nuclear energy user facility. Its mission is to provide nuclear energy researchers access to world-class capabilities and to facilitate the advancement of nuclear science and technology. This mission is supported by providing access to state-of-the-art experimental irradiation testing, post-irradiation examination facilities, and high-performance computing capabilities as well as technical and scientific assistance for the design and execution of projects. Two NSUF irradiation experiments, Boise State University-8242 and General Electric Hitachi-10393, used melt wire packs to determine peak temperatures reached during irradiation testing. This report will discuss the temperature evaluation process and present the associated data.
\end{abstract}

Keywords: In-pile instrumentation, temperature sensor, melt wire, passive sensors 
Page intentionally left blank 


\section{CONTENTS}

ABSTRACT

ACRONYMS viii

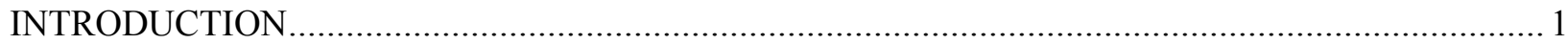

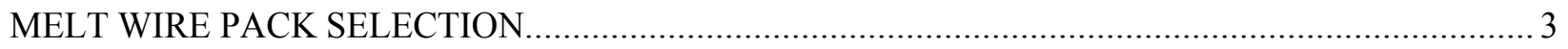

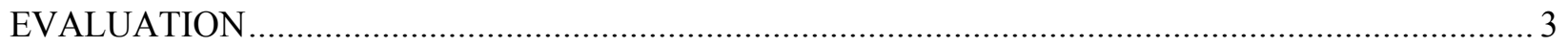

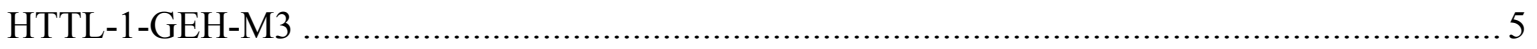

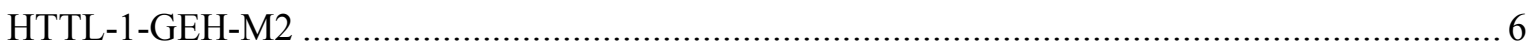

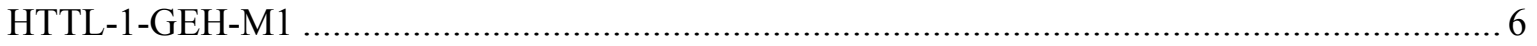

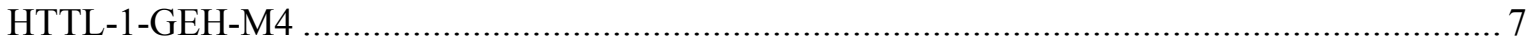

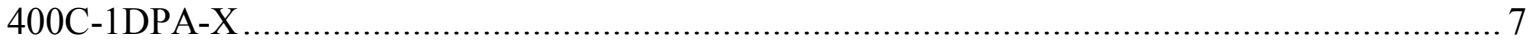

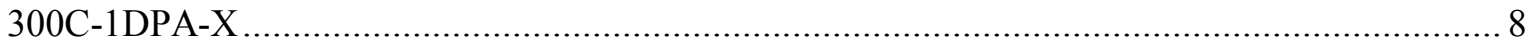

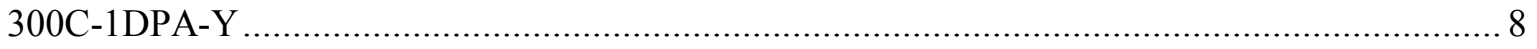

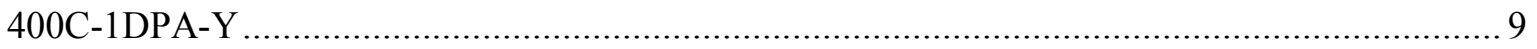

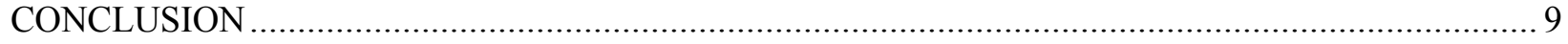

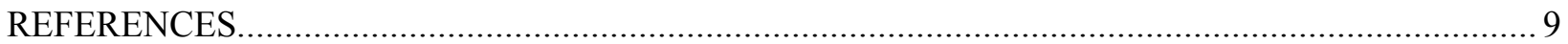

\section{FIGURES}

Figure 1. Typical BSU center fixture with content. ................................................................. 1

Figure 2. Typical BSU center fixture with melt wire pack location................................................... 2

Figure 3. Graphical snip (bottom end to the middle of the GE Hitachi capsule) taken from INL Drawing 605754. Three melt wire packs (HTTL-1-GEH-M3, HTTL-1-GEH-M2, HTTL-1-GEH-M1) are depicted in red. Not depicted was HTTL-1-GEH-M4 located at top of capsule.

Figure 4. Micrograph of pre-Irradiation quartz capsule HTTL-1-GEH-M3. Wire materials (listed in \% weight) are from left to right, $80 \mathrm{Au} 20 \mathrm{Sn}\left(279.5^{\circ} \mathrm{C}\right.$ melt $), 90 \mathrm{~Pb} 5 \mathrm{Ag}, 5 \mathrm{Sn}$ $\left(302.9^{\circ} \mathrm{C}\right.$ melt $), 100 \mathrm{~Pb}\left(327.5^{\circ} \mathrm{C}\right.$ melt $), 85 \mathrm{Te} 15 \mathrm{Sn}\left(399.4^{\circ} \mathrm{C}\right.$ melt $)$.

Figure 5. Photograph of post-Irradiation quartz capsule HTTL-1-GEH-M3. Capsule was broken during removal from experiment. Wire materials (listed in \% weight) are from left to right, $80 \mathrm{Au} 20 \mathrm{Sn}\left(279.5^{\circ} \mathrm{C}\right.$ melt $), 90 \mathrm{~Pb} 5 \mathrm{Ag}, 5 \mathrm{Sn}\left(302.9^{\circ} \mathrm{C}\right.$ melted $), 100 \mathrm{~Pb}\left(327.5^{\circ} \mathrm{C}\right.$ melted), $85 \mathrm{Te} 15 \mathrm{Sn}\left(399.4^{\circ} \mathrm{C}\right.$ no melt).

Figure 6. Micrograph of pre-Irradiation quartz capsule HTTL-1-GEH-M2. Wire materials (listed in \% weight) are from left to right, $95 \mathrm{Sn} 5 \mathrm{Sb}\left(238.6^{\circ} \mathrm{C}\right.$ melt $), 90 \mathrm{~Pb} 10 \mathrm{Sb}\left(252.4^{\circ} \mathrm{C}\right.$ melt), $100 \mathrm{Bi}\left(271.5^{\circ} \mathrm{C}\right.$ melt).

Figure 7. Photograph of post-Irradiation quartz capsule HTTL-1-GEH-M. Photo take through periscope into the hot cell. All melt wire melted.

Figure 8 Micrograph of pre-Irradiation quartz capsule HTTL-1-GEH-M1. Wire materials (listed in \% weight) are from left to right, $95 \mathrm{Sn} 5 \mathrm{Sb}\left(238.6^{\circ} \mathrm{C}\right.$ melt $), 90 \mathrm{~Pb} 10 \mathrm{Sb}\left(252.4^{\circ} \mathrm{C}\right.$ melt), $100 \mathrm{Bi}\left(271.5^{\circ} \mathrm{C}\right.$ melt), $80 \mathrm{Au} 20 \mathrm{Sn}\left(279.5^{\circ} \mathrm{C}\right.$ melt $), 90 \mathrm{~Pb} 5 \mathrm{Ag}, 5 \mathrm{Sn}\left(302.9^{\circ} \mathrm{C}\right.$ melt), $100 \mathrm{~Pb}\left(327.5^{\circ} \mathrm{C}\right.$ melt), $85 \mathrm{Te} 15 \mathrm{Sn}\left(399.4^{\circ} \mathrm{C}\right.$ melt). 
Figure 9 Photograph of post-Irradiation quartz capsule HTTL-1-GEH-M1 as viewed through the hot cell periscope at HFEF. Wire materials (listed in \% weight) are from left to right, $95 \mathrm{Sn} 5 \mathrm{Sb}\left(238.6^{\circ} \mathrm{C}\right.$ melted $), 90 \mathrm{~Pb} 10 \mathrm{Sb}\left(252.4^{\circ} \mathrm{C}\right.$ melted $), 100 \mathrm{Bi}\left(271.5^{\circ} \mathrm{C}\right.$ melted $)$, $80 \mathrm{Au} 20 \mathrm{Sn}\left(279.5^{\circ} \mathrm{C}\right.$ no melt $), 90 \mathrm{~Pb} 5 \mathrm{Ag}, 5 \mathrm{Sn}\left(302.9^{\circ} \mathrm{C}\right.$ quartz clouded not visible), $100 \mathrm{~Pb}\left(327.5^{\circ} \mathrm{C}\right.$ quartz clouded not visible), $85 \mathrm{Te} 15 \mathrm{Sn}\left(399.4^{\circ} \mathrm{C}\right.$ not in photo).

Figure 10 Micrograph of prototype similar to HTTL-1-GEH-M1. Out-of-pile tested to $313^{\circ} \mathrm{C}$.

Figure 11 Micrograph of pre-Irradiation quartz capsule HTTL-1-GEH-M4. Wire materials (listed in \% weight) are from left to right, $95 \mathrm{Sn} 5 \mathrm{Sb}\left(238.6^{\circ} \mathrm{C}\right.$ melt $), 90 \mathrm{~Pb} 10 \mathrm{Sb}\left(252.4^{\circ} \mathrm{C}\right.$ melt), $100 \mathrm{Bi}\left(271.5^{\circ} \mathrm{C}\right.$ melt $), 80 \mathrm{Au} 20 \mathrm{Sn}\left(279.5^{\circ} \mathrm{C}\right.$ melt $), 90 \mathrm{~Pb} 5 \mathrm{Ag}, 5 \mathrm{Sn}\left(302.9^{\circ} \mathrm{C}\right.$ melt), $100 \mathrm{~Pb}\left(327.5^{\circ} \mathrm{C}\right.$ melt $), 85 \mathrm{Te} 15 \mathrm{Sn}\left(399.4^{\circ} \mathrm{C}\right.$ melt $)$.

Figure 12. Micrograph of pre-Irradiation quartz capsule 400C-1DPA-X. Wire materials (listed in $\%$ weight $)$ are from left to right, $100 \mathrm{~Pb}\left(327.5^{\circ} \mathrm{C}\right.$ melt $), 85 \mathrm{Te} 15 \mathrm{Sn}\left(399.4^{\circ} \mathrm{C}\right.$ melt $)$, $100 \mathrm{Te}\left(449.5^{\circ} \mathrm{C}\right.$ melt $)$.

Figure 13. Photograph of post-Irradiation quartz capsule 400C-1DPA-X as viewed through the hot cell periscope at HFEF. 8

Figure 14. Micrograph of pre-Irradiation quartz capsule HTTL-1-GEH-M1. Wire materials (listed in \% weight) are from left to right, $95 \mathrm{Sn} 5 \mathrm{Sb}\left(238.6^{\circ} \mathrm{C}\right.$ melt $), 100 \mathrm{Bi}\left(271.5^{\circ} \mathrm{C}\right.$ melt), $100 \mathrm{~Pb}\left(327.5^{\circ} \mathrm{C}\right.$ melt $)$. 8

Figure 15 Micrograph of pre-Irradiation quartz capsule HTTL-1-GEH-M1. Wire materials (listed in \% weight) are from left to right, $95 \mathrm{Sn} 5 \mathrm{Sb}\left(238.6^{\circ} \mathrm{C}\right.$ melt $), 100 \mathrm{Bi}\left(271.5^{\circ} \mathrm{C}\right.$ melt $)$, $100 \mathrm{~Pb}\left(327.5^{\circ} \mathrm{C}\right.$ melt $)$. 8

Figure 16. Micrograph of pre-Irradiation quartz capsule 400C-1DPA-Y. Wire materials (listed in $\%$ weight $)$ are from left to right, $100 \mathrm{~Pb}\left(327.5^{\circ} \mathrm{C}\right.$ melt $), 85 \mathrm{Te} 15 \mathrm{Sn}\left(399.4^{\circ} \mathrm{C}\right.$ melt $)$, $100 \mathrm{Te}\left(449.5^{\circ} \mathrm{C}\right.$ melt $)$.

\section{TABLES}

Table 1. Identification of melt wire pack, wires in each pack and the evaluated temperature range, T....... 4 
Page intentionally left blank 


\section{ACRONYMS}

$\begin{array}{ll}\text { AM } & \text { additive manufactured } \\ \text { ATR } & \text { Advanced Test Reactor } \\ \text { BSU } & \text { Boise State University } \\ \text { DMLM } & \text { direct metal laser melting } \\ \text { DSC } & \text { differential scanning calorimeter } \\ \text { GE } & \text { General Electric } \\ \text { GEH } & \text { General Electric Hitachi } \\ \text { HFEF } & \text { Hot Fuel Examination Facility } \\ \text { HIP } & \text { hot isostatic pressing } \\ \text { HTTL } & \text { High Temperature Test Laboratory } \\ \text { INL } & \text { Idaho National Laboratory } \\ \text { NSUF } & \text { Nuclear Science User Facilities } \\ \text { PIE } & \text { post-irradiation examination } \\ \text { PM } & \text { powder metallurgy }\end{array}$


Page intentionally left blank

ix 


\section{NSUF Melt Wire Evaluations for BSU-8242 and GE Hitachi-10393 Irradiation Experiments \\ INTRODUCTION}

The Boise State University-8242 Experiment (BSU-8242) [1] was a drop-in design irradiated in the Advanced Test Reactor (ATR). The objective of this experiment was to assess the viability of using alloys manufactured by powder metallurgy and hot isostatic pressing (PM HIP) as materials used in nuclear reactor components. Five experiments were performed. This evaluation is for the melt wires extracted from Experiments 4 and 5. Figure 1 shows a typical center fixture, and Figure 2 shows the location of the melt wire pack in the center fixture.

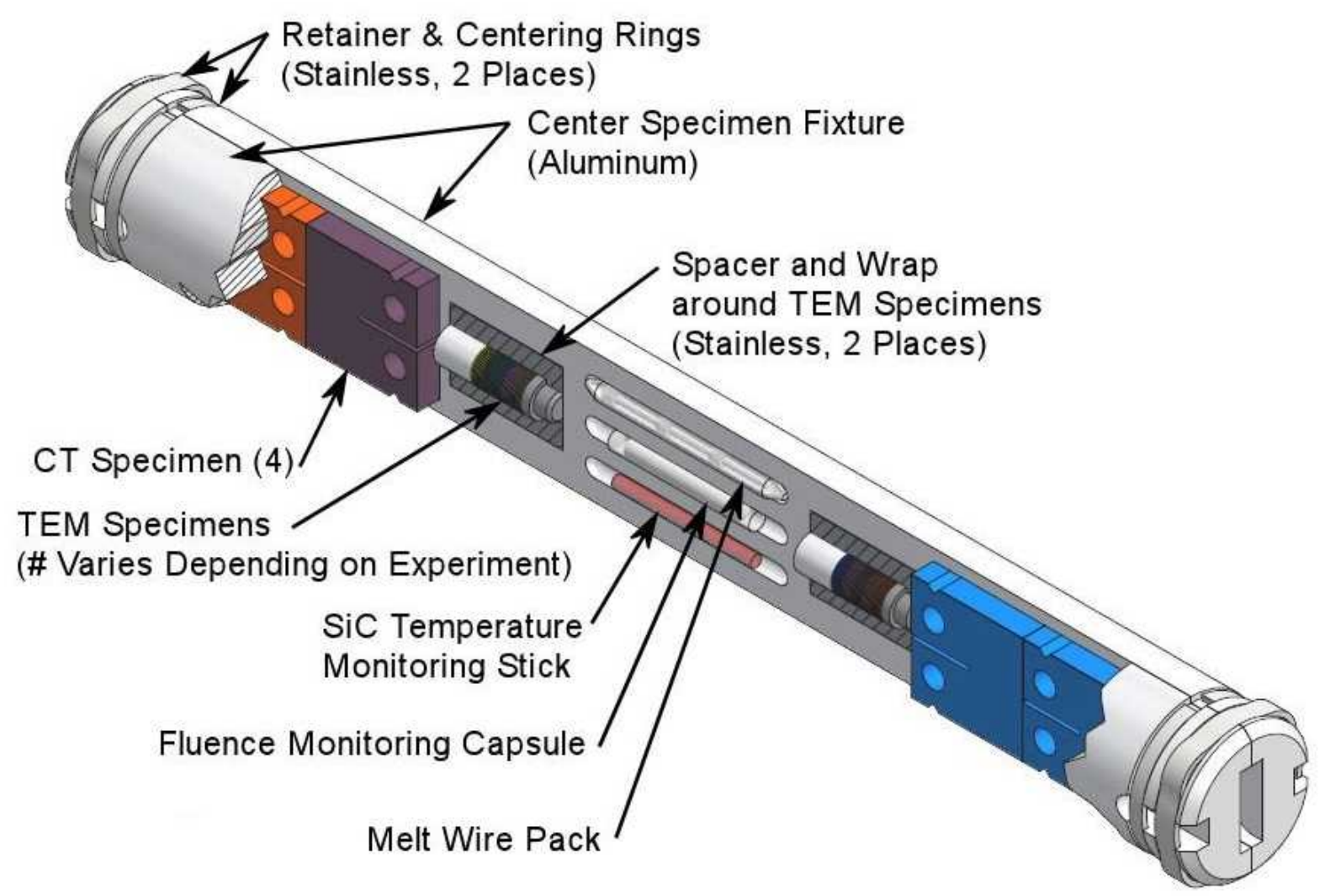

Figure 1. Typical BSU center fixture with content. 


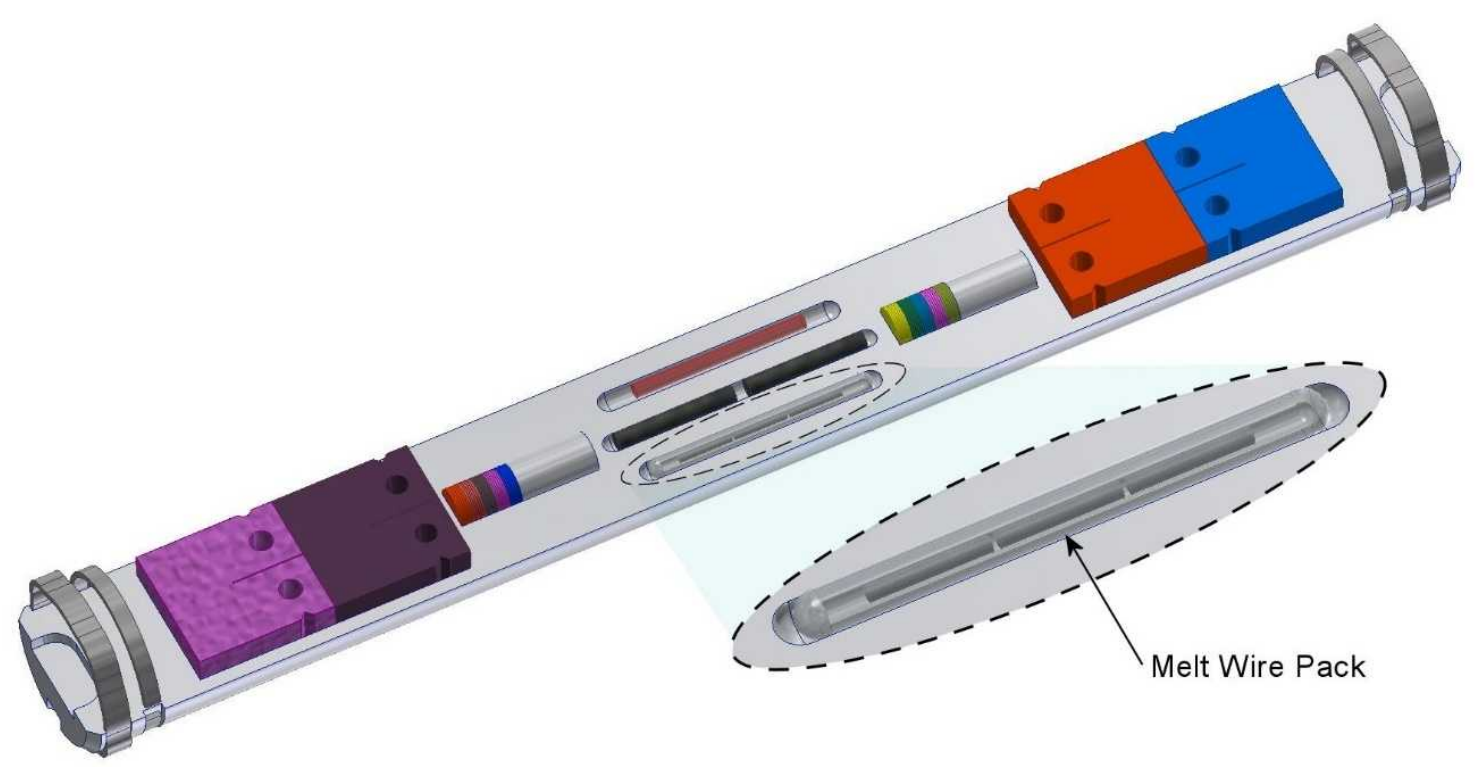

Figure 2. Typical BSU center fixture with melt wire pack location.

The purpose of the General Electric (GE) Hitachi-10393 Experiment [2] was to perform full irradiation / post-irradiation examination (PIE) on materials produced by direct metal laser melting (DMLM) a method of additive manufactured (AM) material fabrication. This experiment was a drop-in experiment irradiated in position B-11 at the ATR. The objective of this experiment was to compare the properties of the irradiated AM specimens to the AM properties in the un-irradiated condition. Four melt wire packs were used in this experiment. Figure 3 is an illustration showing the placement of three of the melt wire packs in the capsule. 


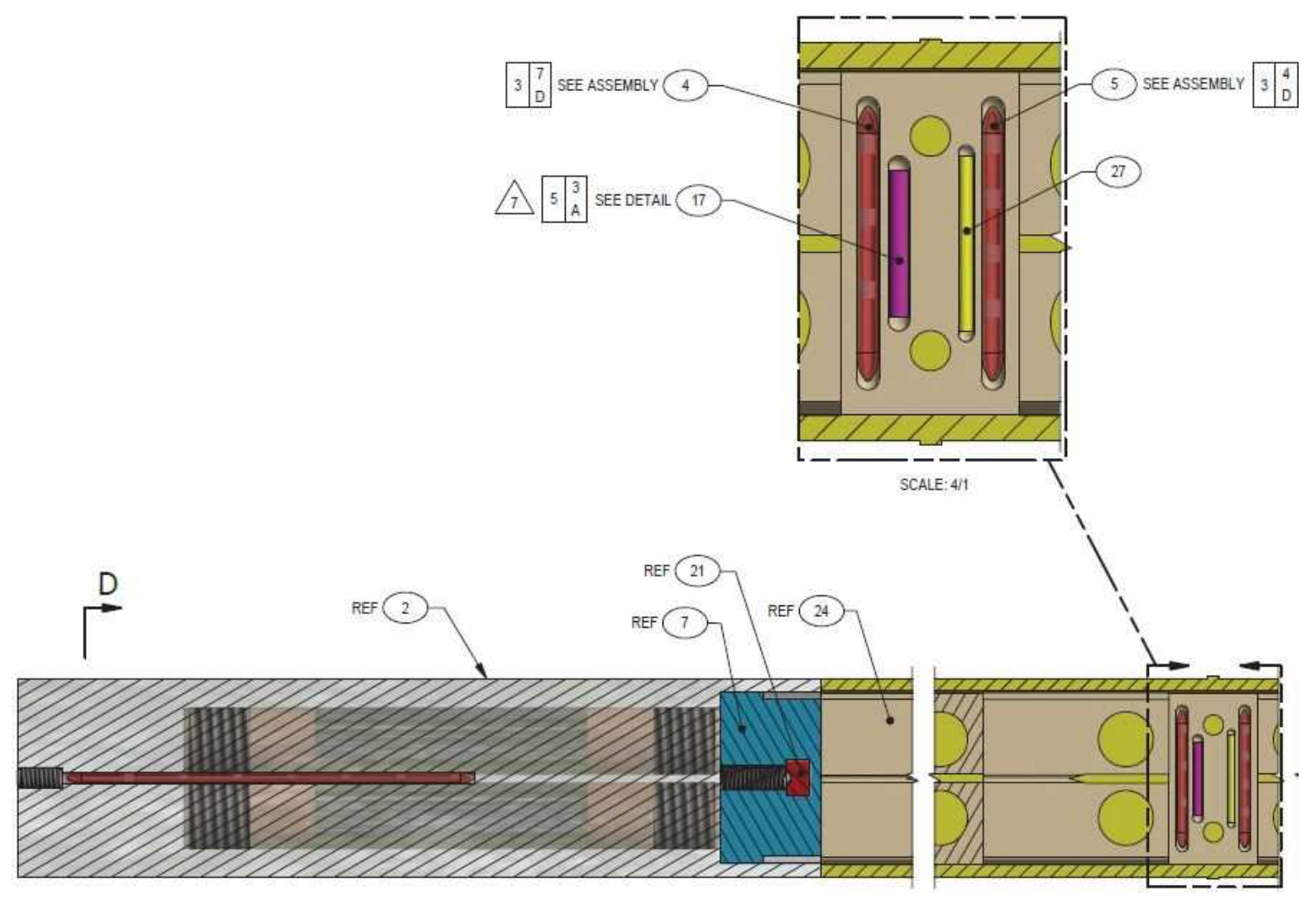

Figure 3. Graphical snip (bottom end to the middle of the GE Hitachi capsule) taken from INL Drawing 605754. Three melt wire packs (HTTL-1-GEH-M3, HTTL-1-GEH-M2, HTTL-1-GEH-M1) are depicted in red. Not depicted was HTTL-1-GEH-M4 located at top of capsule.

\section{MELT WIRE PACK SELECTION}

The melt wire packs listed in Table 1 were assembled with individual melt wires to bound estimated temperatures for both the BSU-8242 and GE Hitachi (GEH) tests. These materials were selected from a library of melt wire materials maintained by Idaho National Laboratory's (INL's) High Temperature Test Laboratory (HTTL).[3] Wires included in each pack had their melting temperature evaluated using a Netzsch differential scanning calorimeter (DSC) to detect heat absorption of the sample as it undergoes the endothermic phase transition from solid to liquid. This information provides melting point data of the actual material stock to be used in the experiment rather than relying on standard data. $[4,5]$ In addition, furnace tests of prototype packs were conducted to examine performance, observe material interactions between melt wires or quartz containment tube, and to provide the insight required to visually discern melting after heating in the quartz encapsulated tubes. [6]

\section{EVALUATION}

Post-irradiation visual examination of melt wire packs from experiments BSU-8242 and GE Hitachi10393 were performed at the INL Hot Fuels Examination Facility (HFEF). Drawings 605744, ATR BSU8242 SPECIMEN ASSEMBLIES AND DETAILS, and 605754, ATR GE HITACHI (GEH) CAPSULE DETAILS AND ASSEMBLY document melt wire pack design and configuration. In total, eight melt wire packs where evaluated with four from each experiment. The experience of the manipulator operator was critical in completing the evaluation, as they are the only personnel during the evaluation that can observe motion of the wires inside the pack. The packs were too small to observe through the viewing window, therefore a periscope with 20x magnification was used to visually inspect each pack. Pre- 
irradiation micrographs of each melt wire pack were used during the evaluation to determine melt geometries and spacer locations. The results are presented in Table 1.

Table 1. Identification of melt wire pack, wires in each pack and the evaluated temperature range, $\mathrm{T}$.

\begin{tabular}{|c|c|c|c|c|}
\hline $\begin{array}{l}\text { Melt wire Pack } \\
\text { Serial Number }\end{array}$ & $\begin{array}{c}\text { Experiment/HFEF } \\
\text { Sample ID }\end{array}$ & $\begin{array}{l}\% \text { weight each wire in } \\
\text { package and (melt } \\
\text { temperature) }\end{array}$ & $\begin{array}{l}\text { Temperature } \\
\text { (T) Range }\end{array}$ & Notes \\
\hline HTTL-1-GEH-M3 & $\begin{array}{l}\text { GEG/GEH- } \\
\text { MELTWIRE3-1 }\end{array}$ & $\begin{array}{l}80 \mathrm{Au} 20 \mathrm{Sn}\left(279.5^{\circ} \mathrm{C}\right) \text {, } \\
90 \mathrm{~Pb} 5 \mathrm{Ag}, 5 \mathrm{Sn} \\
\left(302.9^{\circ} \mathrm{C}\right), 100 \mathrm{~Pb} \\
\left(327.5^{\circ} \mathrm{C}\right), 85 \mathrm{Te} 15 \mathrm{Sn} \\
\left(399.4^{\circ} \mathrm{C}\right) .\end{array}$ & $\begin{array}{l}327.5^{\circ} \mathrm{C}<\mathrm{T}< \\
399.4^{\circ} \mathrm{C}\end{array}$ & \\
\hline HTTL-1-GEH-M2 & $\begin{array}{l}\text { GEG/GEH- } \\
\text { MELTWIRE4-1 }\end{array}$ & $\begin{array}{l}95 \mathrm{Sn} 5 \mathrm{Sb}\left(238.6^{\circ} \mathrm{C}\right), 90 \\
\mathrm{~Pb} 10 \mathrm{Sb}\left(252.4^{\circ} \mathrm{C}\right), 100 \\
\mathrm{Bi}\left(271.5^{\circ} \mathrm{C}\right)\end{array}$ & $\mathrm{T}>271.5^{\circ} \mathrm{C}$ & $\begin{array}{l}\text { All wires } \\
\text { melted }\end{array}$ \\
\hline HTTL-1-GEH-M1 & $\begin{array}{l}\text { GEG/GEH- } \\
\text { MELTWIRE7-2 }\end{array}$ & $\begin{array}{l}95 \mathrm{Sn} 5 \mathrm{Sb}\left(238.6^{\circ} \mathrm{C}\right), 90 \\
\mathrm{~Pb} 10 \mathrm{Sb}\left(252.4^{\circ} \mathrm{C}\right), 100 \\
\mathrm{Bi}\left(271.5^{\circ} \mathrm{C}\right), 80 \mathrm{Au} 20 \\
\mathrm{Sn}\left(279.5^{\circ} \mathrm{C}\right), 90 \mathrm{~Pb} 5 \mathrm{Ag}, \\
5 \mathrm{Sn}\left(302.9^{\circ} \mathrm{C}\right), 100 \mathrm{~Pb} \\
\left(327.5^{\circ} \mathrm{C}\right), 85 \mathrm{Te} 15 \mathrm{Sn} \\
\left(399.4^{\circ} \mathrm{C}\right)\end{array}$ & $\begin{array}{l}271.5^{\circ} \mathrm{C}<\mathrm{T}< \\
279.5^{\circ} \mathrm{C}\end{array}$ & \\
\hline HTTL-1-GEH-M4 & $\begin{array}{l}\text { GEG/GEH- } \\
\text { MELTWIRE7-1 }\end{array}$ & $\begin{array}{l}95 \mathrm{Sn} 5 \mathrm{Sb}\left(238.6^{\circ} \mathrm{C}\right), 90 \\
\mathrm{~Pb} 10 \mathrm{Sb}\left(252.4^{\circ} \mathrm{C}\right), 100 \\
\mathrm{Bi}\left(271.5^{\circ} \mathrm{C}\right), 80 \mathrm{Au} 20 \\
\mathrm{Sn}\left(279.5^{\circ} \mathrm{C}\right), 90 \mathrm{~Pb} 5 \mathrm{Ag}, \\
5 \mathrm{Sn}\left(302.9^{\circ} \mathrm{C}\right), 100 \mathrm{~Pb} \\
\left(327.5^{\circ} \mathrm{C}\right), 85 \mathrm{Te} 15 \mathrm{Sn} \\
\left(399.4^{\circ} \mathrm{C}\right)\end{array}$ & $\begin{array}{l}327.5^{\circ} \mathrm{C}<\mathrm{T}< \\
399.4^{\circ} \mathrm{C}\end{array}$ & \\
\hline 400C-1DPA-X & BSU/MELTWRE4 & $\begin{array}{l}100 \mathrm{~Pb}\left(327.5^{\circ} \mathrm{C}\right), 85 \mathrm{Te} \\
15 \mathrm{Sn}\left(399.4^{\circ} \mathrm{C}\right), 100 \mathrm{Te} \\
\left(449.5^{\circ} \mathrm{C}\right) .\end{array}$ & $\begin{array}{l}327.5^{\circ} \mathrm{C}<\mathrm{T} \\
399.4^{\circ} \mathrm{C}\end{array}$ & \\
\hline 300C-1DPA-X & BSU/MELTWRE1 & $\begin{array}{l}95 \mathrm{Sn} 5 \mathrm{Sb}\left(238.6^{\circ} \mathrm{C}\right), \\
100 \mathrm{Bi}\left(271.5^{\circ} \mathrm{C}\right), 100 \mathrm{~Pb} \\
\left(327.5^{\circ} \mathrm{C}\right)\end{array}$ & $\mathrm{T}<238.6^{\circ} \mathrm{C}$ & $\begin{array}{l}\text { No melt } \\
\text { detected }\end{array}$ \\
\hline 300C-1DPA-Y & BSU/MELTWRE2 & $\begin{array}{l}95 \mathrm{Sn} 5 \mathrm{Sb}\left(238.6^{\circ} \mathrm{C}\right), \\
100 \mathrm{Bi}\left(271.5^{\circ} \mathrm{C}\right), 100 \mathrm{~Pb} \\
\left(327.5^{\circ} \mathrm{C}\right) .\end{array}$ & $\begin{array}{l}238.6^{\circ} \mathrm{C}<\mathrm{T} \\
<271.5^{\circ} \mathrm{C}\end{array}$ & \\
\hline 400C-1DPA-Y & BSU/MELTWRE5 & $\begin{array}{l}100 \mathrm{~Pb}\left(327.5^{\circ} \mathrm{C}\right), 85 \mathrm{Te} \\
15 \mathrm{Sn}\left(399.4^{\circ} \mathrm{C}\right), 100 \mathrm{Te} \\
\left(449.5^{\circ} \mathrm{C}\right) .\end{array}$ & $\begin{array}{l}399.4^{\circ} \mathrm{C}<\mathrm{T}< \\
449.5^{\circ} \mathrm{C}\end{array}$ & \\
\hline
\end{tabular}

A discussion of each melt wire pack follows. 


\section{HTTL-1-GEH-M3}

Figure 4 shows the pre-irradiation quartz capsule, and Figure 5 shows the broken remains of the capsule and contents after it was removed from the experiment in HFEF. Evaluation of this capsule consisted of carefully comparing the pre-irradiation micrograph to what could be seen in the hot cell. After accounting for all the wire pieces, it was determined that the only wire that did not melt was the $85 \mathrm{Te} 15 \mathrm{Sn}$. The evaluated temperature range for this capsule is $327.5^{\circ} \mathrm{C}<\mathrm{T}<399.4^{\circ} \mathrm{C}$.

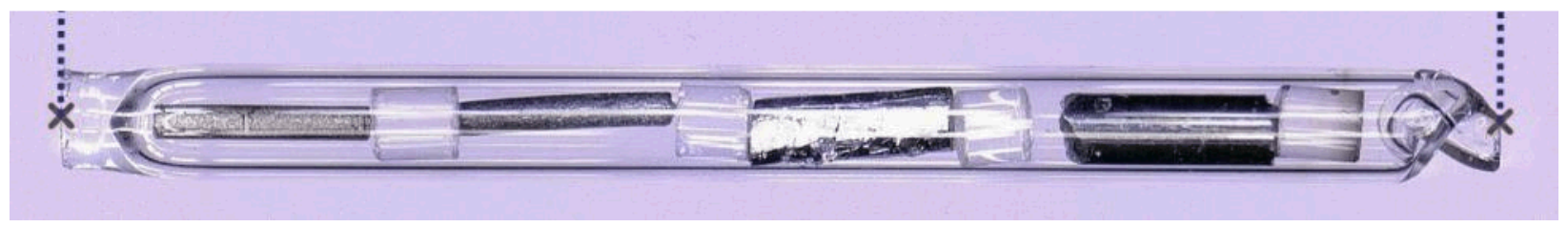

Figure 4. Micrograph of pre-Irradiation quartz capsule HTTL-1-GEH-M3. Wire materials (listed in \% weight) are from left to right, $80 \mathrm{Au} 20 \mathrm{Sn}\left(279.5^{\circ} \mathrm{C}\right.$ melt $), 90 \mathrm{~Pb} 5 \mathrm{Ag}, 5 \mathrm{Sn}\left(302.9^{\circ} \mathrm{C}\right.$ melt $), 100 \mathrm{~Pb}$ $\left(327.5^{\circ} \mathrm{C}\right.$ melt $), 85 \mathrm{Te} 15 \mathrm{Sn}\left(399.4^{\circ} \mathrm{C}\right.$ melt $)$.

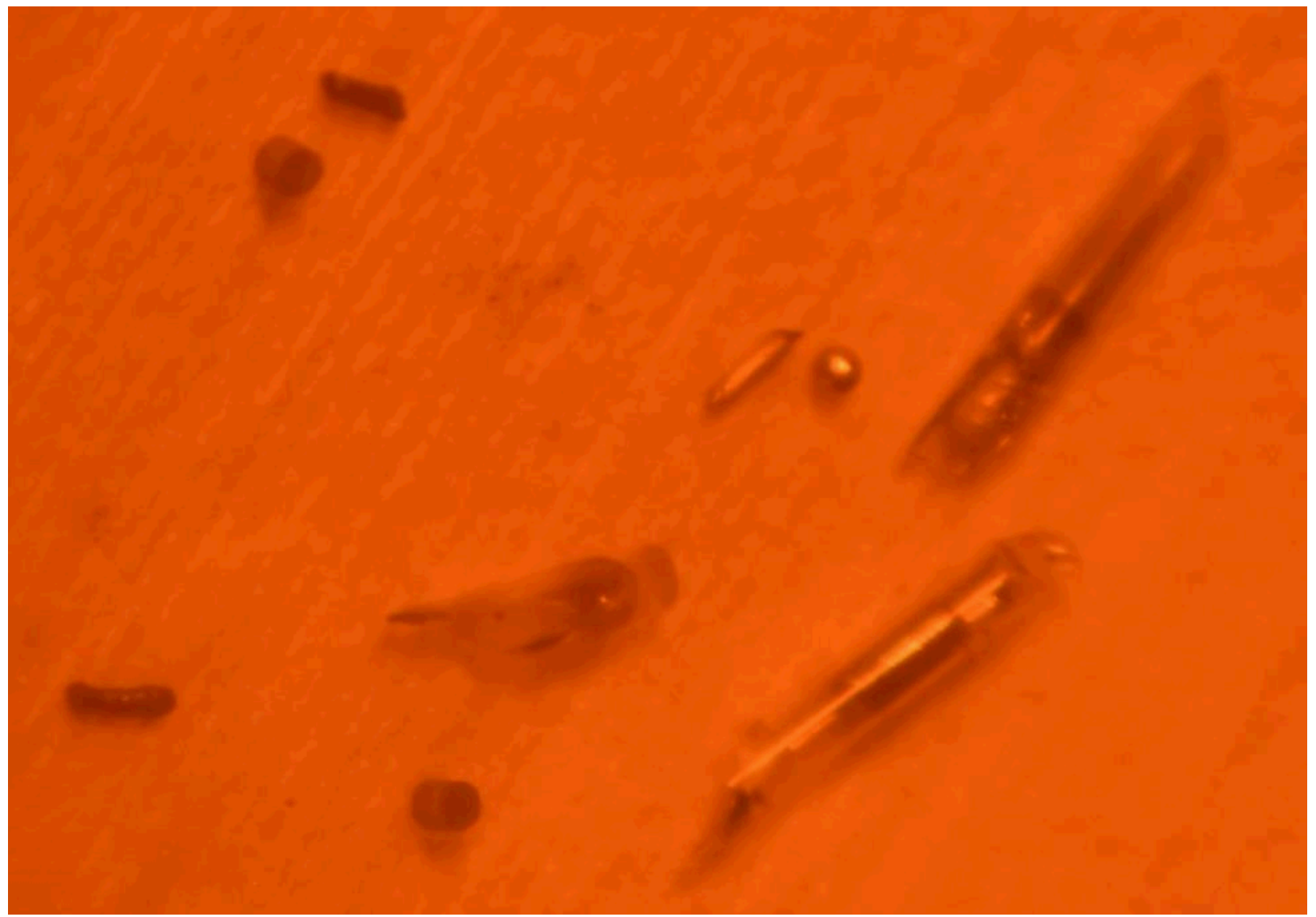

Figure 5. Photograph of post-Irradiation quartz capsule HTTL-1-GEH-M3. Capsule was broken during removal from experiment. Wire materials (listed in \% weight) are from left to right, $80 \mathrm{Au} 20 \mathrm{Sn}$ (279.5 ${ }^{\circ} \mathrm{C}$ melt), $90 \mathrm{~Pb} 5 \mathrm{Ag}, 5 \mathrm{Sn}\left(302.9^{\circ} \mathrm{C}\right.$ melted $), 100 \mathrm{~Pb}\left(327.5^{\circ} \mathrm{C}\right.$ melted $), 85 \mathrm{Te} 15 \mathrm{Sn}\left(399.4^{\circ} \mathrm{C}\right.$ no melt). 


\section{HTTL-1-GEH-M2}

Figure 6 shows the pre-irradiation quartz capsule, and Figure 7 shows post-irradiation capsule held with tweezers in the hot cell via the manipulator. Visual examination through a periscope in a hot cell is not a simple task, requiring the operator to remotely manipulate the capsule to achieve the best lighting conditions. The post-irradiated capsule photo shown in Figure 7, with optimal lighting and precise positioning of the quartz tube, reveals that all melt wires had melted. The evaluated temperature range for this quartz capsule is $\mathrm{T}>271.5^{\circ} \mathrm{C}$.

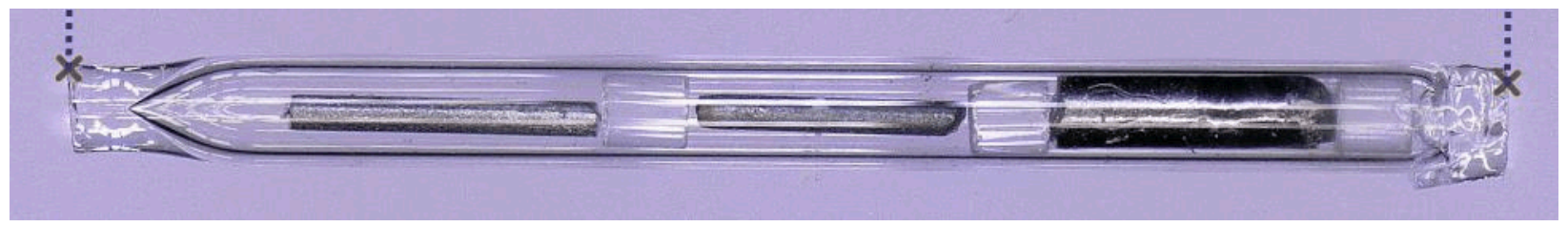

Figure 6. Micrograph of pre-Irradiation quartz capsule HTTL-1-GEH-M2. Wire materials (listed in \% weight) are from left to right, $95 \mathrm{Sn} 5 \mathrm{Sb}\left(238.6^{\circ} \mathrm{C}\right.$ melt $), 90 \mathrm{~Pb} 10 \mathrm{Sb}\left(252.4^{\circ} \mathrm{C}\right.$ melt $), 100 \mathrm{Bi}\left(271.5^{\circ} \mathrm{C}\right.$ melt).

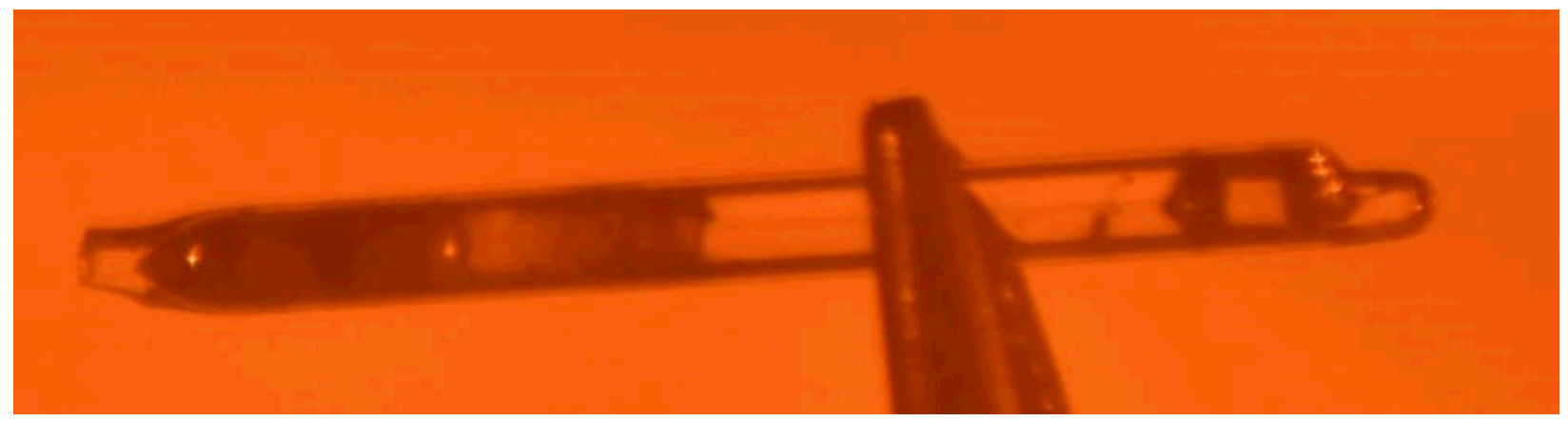

Figure 7. Photograph of post-Irradiation quartz capsule HTTL-1-GEH-M. Photo taken through periscope into the hot cell. All melt wires melted.

\section{HTTL-1-GEH-M1}

Figure 8 shows the pre-irradiation quartz capsule, and Figure 9 shows the post-irradiation capsule held with tweezers in the hot cell via the manipulator. From these figures, it is evident that the first three melt wires melted. Visual inspection found that the $80 \mathrm{Au} 20 \mathrm{Sn}$ wire had some deformation, but, upon further inspection and comparison to the pre-irradiation micrograph, it was determined that this deformation was present before irradiation. Without the pre-irradiation micrograph, this evaluation could have determined a higher melt temperature. The $80 \mathrm{Au} 20 \mathrm{Sn}$ wire can be seen in Figure 9. The view of melt wires $90 \mathrm{~Pb} 5 \mathrm{Ag}$ and $100 \mathrm{~Pb}$ was obstructed by staining of the inner quartz surface. It is speculated that this may be the result of oxidation in the melt pack.

Figure 10 is a micrograph of a prototype capsule similar to HTTL-1-GEH-M1. It was tested in a furnace to $313^{\circ} \mathrm{C}$, a temperature above the melting temperature of the $80 \mathrm{Au} 20 \mathrm{Sn}$ wire. It is interesting to note that no staining of the inner quartz tube is observable that is similar to what was observed for HTTL-1-GEH-M1. On the prototype, there are faint regions where melt wires may have sublimated and plated out on the inner surface of the quartz tube. Once the melt wire melts and relocates downward, these regions become readily visible.

The last melt wire (85 Te $15 \mathrm{Sn}$ ) in HTTL-1-GEH-M1 was visible during the examination and it was intact. Based on this examination, the temperature experienced by HTTL-1-GEH-M1 was between $271.5^{\circ} \mathrm{C}$ and $279.5^{\circ} \mathrm{C}$. 
Figure 8. Micrograph of pre-Irradiation quartz capsule HTTL-1-GEH-M1. Wire materials (listed in \% weight) are from left to right, $95 \mathrm{Sn} 5 \mathrm{Sb}\left(238.6^{\circ} \mathrm{C}\right.$ melt $), 90 \mathrm{~Pb} 10 \mathrm{Sb}\left(252.4^{\circ} \mathrm{C}\right.$ melt $), 100 \mathrm{Bi}\left(271.5^{\circ} \mathrm{C}\right.$ melt), $80 \mathrm{Au} 20 \mathrm{Sn}\left(279.5^{\circ} \mathrm{C}\right.$ melt $), 90 \mathrm{~Pb} 5 \mathrm{Ag}, 5 \mathrm{Sn}\left(302.9^{\circ} \mathrm{C}\right.$ melt), $100 \mathrm{~Pb}\left(327.5^{\circ} \mathrm{C}\right.$ melt $), 85 \mathrm{Te} 15 \mathrm{Sn}$ $\left(399.4^{\circ} \mathrm{C}\right.$ melt).

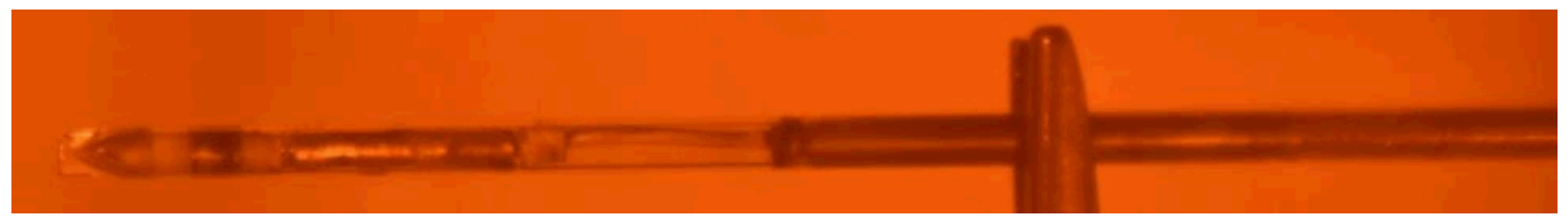

Figure 9. Photograph of post-Irradiation quartz capsule HTTL-1-GEH-M1 as viewed through the hot cell periscope at HFEF. Wire materials (listed in \% weight) are from left to right, $95 \mathrm{Sn} 5 \mathrm{Sb}\left(238.6^{\circ} \mathrm{C}\right.$ melted), $90 \mathrm{~Pb} 10 \mathrm{Sb}\left(252.4^{\circ} \mathrm{C}\right.$ melted), $100 \mathrm{Bi}\left(271.5^{\circ} \mathrm{C}\right.$ melted $), 80 \mathrm{Au} 20 \mathrm{Sn}\left(279.5^{\circ} \mathrm{C}\right.$ no melt $), 90 \mathrm{~Pb}$ $5 \mathrm{Ag}, 5 \mathrm{Sn}\left(302.9^{\circ} \mathrm{C}\right.$ quartz clouded not visible), $100 \mathrm{~Pb}\left(327.5^{\circ} \mathrm{C}\right.$ quartz clouded not visible), $85 \mathrm{Te} 15 \mathrm{Sn}$ $\left(399.4^{\circ} \mathrm{C}\right.$ not in photo).

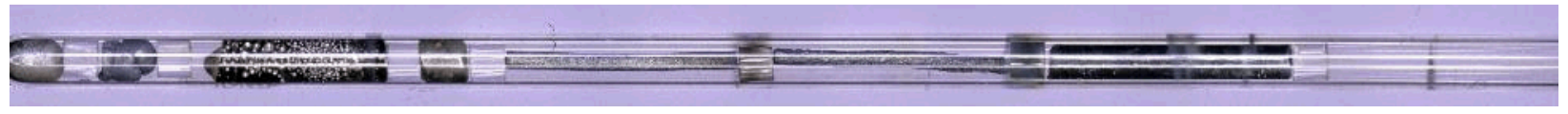

Figure 10. Micrograph of prototype similar to HTTL-1-GEH-M1. Out-of-pile tested to $313^{\circ} \mathrm{C}$.

\section{HTTL-1-GEH-M4}

Figure 11 shows the pre-irradiation quartz capsule. No post-irradiation photo was taken. Oxidation very similar to that shown in Figure 9 was present. Shaking the quartz capsule during visual inspection moved the melt wires making it possible to see around the staining on the inner wall. From this, it was determined that the $100 \mathrm{~Pb}$ (and all cooler melt wires) had melted and that the $85 \mathrm{Te} 15 \mathrm{Sn}$ was intact. From this, the temperature experienced by HTTL-1-GEH-M4 was between $327.5^{\circ} \mathrm{C}$ and $399.4^{\circ} \mathrm{C}$

Figure 11. Micrograph of pre-Irradiation quartz capsule HTTL-1-GEH-M4. Wire materials (listed in \% weight) are from left to right, $95 \mathrm{Sn} 5 \mathrm{Sb}\left(238.6^{\circ} \mathrm{C}\right.$ melt $), 90 \mathrm{~Pb} 10 \mathrm{Sb}\left(252.4^{\circ} \mathrm{C}\right.$ melt $), 100 \mathrm{Bi}\left(271.5^{\circ} \mathrm{C}\right.$ melt), $80 \mathrm{Au} 20 \mathrm{Sn}\left(279.5^{\circ} \mathrm{C}\right.$ melt $), 90 \mathrm{~Pb} 5 \mathrm{Ag}, 5 \mathrm{Sn}\left(302.9^{\circ} \mathrm{C}\right.$ melt $), 100 \mathrm{~Pb}\left(327.5^{\circ} \mathrm{C}\right.$ melt $), 85 \mathrm{Te} 15 \mathrm{Sn}$ $\left(399.4^{\circ} \mathrm{C}\right.$ melt).

\section{C-1DPA-X}

Figure 12 shows the pre-irradiation quartz capsule, and Figure 13 shows the post-irradiation capsule held with tweezers in the hot cell via the manipulator. The (Figure 13) hot cell photo for this sample was blurred, but visual inspection determined that only the first melt wire had melted. Lighting and surface reflectance of the quarts for the BSU project interfered with photography, hence no other BSU quartz capsules were photographed. Visual inspections were more convenient and conclusive. Based on visual inspection, the temperature range experienced by this capsule was between $327.5^{\circ} \mathrm{C}$ and $399.4^{\circ} \mathrm{C}$. 


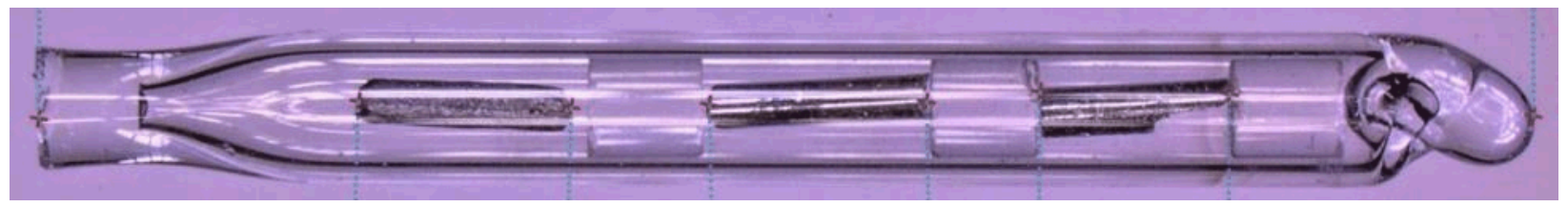

Figure 12. Micrograph of pre-Irradiation quartz capsule 400C-1DPA-X. Wire materials (listed in \% weight) are from left to right, $100 \mathrm{~Pb}\left(327.5^{\circ} \mathrm{C}\right.$ melt $), 85 \mathrm{Te} 15 \mathrm{Sn}\left(399.4^{\circ} \mathrm{C}\right.$ melt $), 100 \mathrm{Te}\left(449.5^{\circ} \mathrm{C}\right.$ melt $)$.

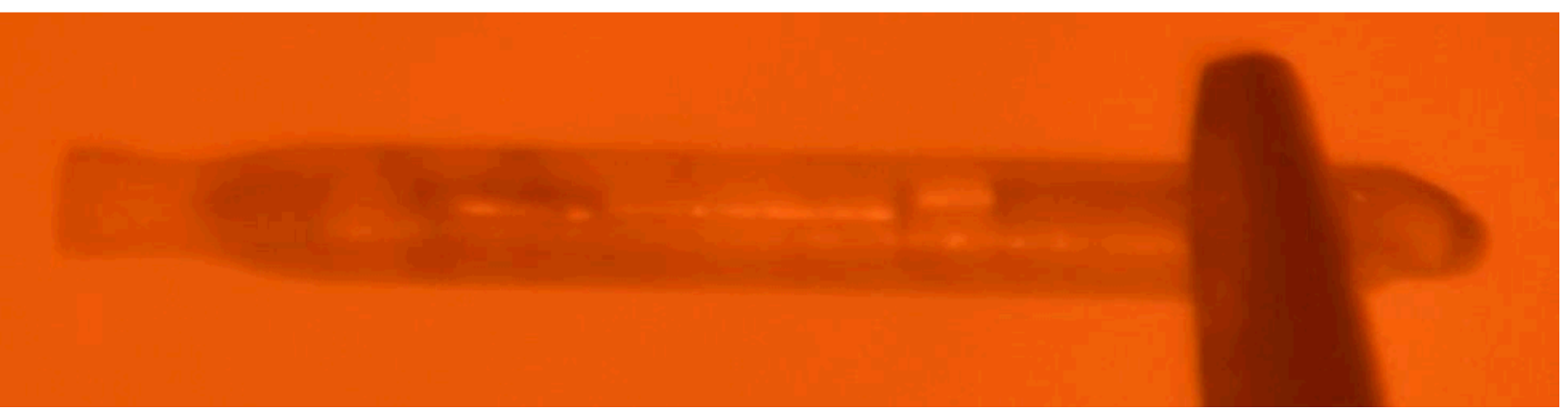

Figure 13. Photograph of post-Irradiation quartz capsule 400C-1DPA-X as viewed through the hot cell periscope at HFEF.

\section{C-1DPA-X}

Figure 14 shows the pre-irradiation quartz capsule. No post-irradiation photo was taken. Visual inspection revealed that no melt wires melted. Thus, the temperature that $300 \mathrm{C}-1 \mathrm{DPA}-\mathrm{X}$ was exposed to was less than $238.6^{\circ} \mathrm{C}$

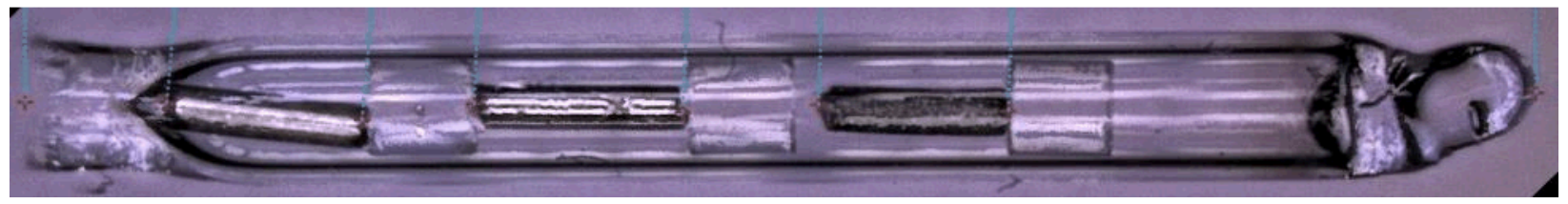

Figure 14. Micrograph of pre-Irradiation quartz capsule HTTL-1-GEH-M1. Wire materials (listed in \% weight) are from left to right, $95 \mathrm{Sn} 5 \mathrm{Sb}\left(238.6^{\circ} \mathrm{C}\right.$ melt $), 100 \mathrm{Bi}\left(271.5^{\circ} \mathrm{C}\right.$ melt $), 100 \mathrm{~Pb}\left(327.5^{\circ} \mathrm{C}\right.$ melt $)$.

\section{C-1DPA-Y}

Figure 15 shows the pre-irradiation quartz capsule. No post-irradiation photo was taken. Visual examination revealed that only the $95 \mathrm{Sn} 5 \mathrm{Sb}$ melt wire had melted. Based on this evaluation, the temperature range experienced by $300 \mathrm{C}-1 \mathrm{DPA}-\mathrm{Y}$ was between $238.6^{\circ} \mathrm{C}$ and $271.5^{\circ} \mathrm{C}$

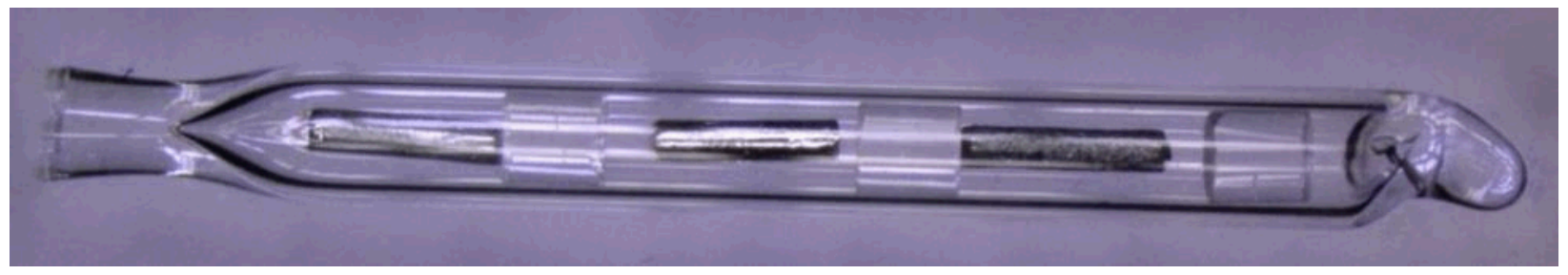

Figure 15. Micrograph of pre-Irradiation quartz capsule HTTL-1-GEH-M1. Wire materials (listed in \% weight) are from left to right, $95 \mathrm{Sn} 5 \mathrm{Sb}\left(238.6^{\circ} \mathrm{C}\right.$ melt $), 100 \mathrm{Bi}\left(271.5^{\circ} \mathrm{C}\right.$ melt $), 100 \mathrm{~Pb}\left(327.5^{\circ} \mathrm{C}\right.$ melt $)$. 


\section{C-1DPA-Y}

Figure 16 shows the pre-irradiation quartz capsule. No post-irradiation photo was taken. Visual examination revealed that both the $100 \mathrm{~Pb}$ and $85 \mathrm{Te} 15 \mathrm{Sn}$ melt wires had melted. Based on this evaluation, the temperature range experienced by $400 \mathrm{C}-1 \mathrm{DPA}-\mathrm{Y}$ was between $399.4^{\circ} \mathrm{C}$ and $449.5^{\circ} \mathrm{C}$.

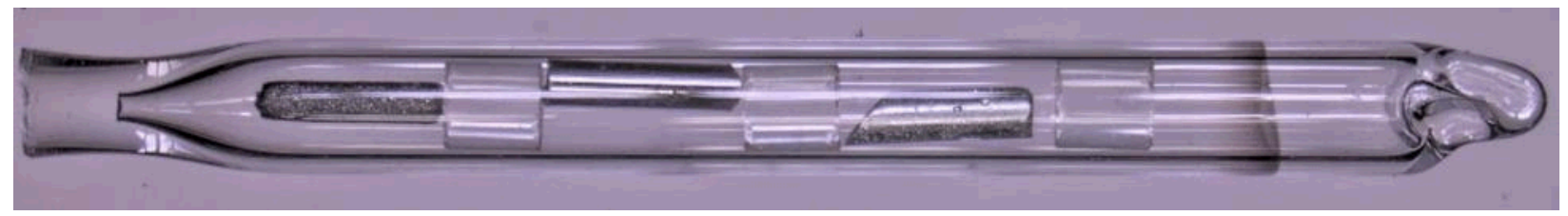

Figure 16. Micrograph of pre-Irradiation quartz capsule 400C-1DPA-Y. Wire materials (listed in \% weight) are from left to right, $100 \mathrm{~Pb}\left(327.5^{\circ} \mathrm{C}\right.$ melt $), 85 \mathrm{Te} 15 \mathrm{Sn}\left(399.4^{\circ} \mathrm{C}\right.$ melt $), 100 \mathrm{Te}\left(449.5^{\circ} \mathrm{C}\right.$ melt $)$.

\section{CONCLUSION}

Melt Wires designed and fabricated by HTTL provide visual evidence during post irradiation examination to identify maximum temperatures reached in specified areas of an experiment. HTTL has been providing melt wires for NSUF experiments for many years to supply a simple, yet effective way to determine these temperatures. This evaluation was provided for two NSUF experiments: BSU 8242 and GE Hitachi-10393. Eight melt wire packs were successfully evaluated. Seven of the eight packs remained intact during the evaluation at HFEF; although the eighth pack broke during handling, it was still readable. It was observed that the larger melt wire packs (HTTL-1-GEH-M1 and HTTL-1-GEH-M4) experienced oxidation during the irradiation. It is speculated that the larger design is not conducive to oxygen elimination during the manufacturing process, although prototype testing did not uncover oxidation anomalies. Visual inspection of the melt wires was achievable at HFEF using the periscope, however, there is room for improvement to provide conclusive visual evidence. A dedicated melt wire inspection system designed with multiple light sources to provide varying intensity and color, specimen rotation and integrated magnifying camera system would be of great benefit. Pre-irradiation microscopy and prototypical performance testing is imperative in obtaining accurate temperature evaluations. Without microscopy and performance testing melt wire packs HTTL-1-GEH-M3, HTTL-1-GEH-M1, and HTTL1-GEH-M4 could have been misread.

\section{REFERENCES}

1. Donna Guillen, et.al., "Boise State University (BSU)-8242 Experiment Execution Plan,” PLN-5248, Rev. 1, Project 32349, April 2017.

2. K, Lombard, et. al., "Ge-Hitachi Drop-In Experiment Technical and Functional Requirements." TRF-050, Rev, 1, April 2017.

3. K. L. Davis, D.L. Knudson, J.E. Daw, J.L. Rempe and A.J. Palmer, "Melt Wire Sensors Available to Determine Peak Temperatures in ATR Irradiation Testing," 8th International Topical Meeting on Nuclear Plant Instrumentation, Control, and Human Machine Interface Technologies (NPIC\&HMIT 2012), San Diego, CA, July 22-26, 2012.

4. D. L. Knudson, "Melt Temperatures for the Zr Growth Experiment Melt Wires," TEV-1007, September 2010.

5. K. L. Davis, "Evaluation of Bismuth Sample for Inclusion in HTTL Melt Wire Library," TEV-2986, April 2017.

6. K.L. Davis, “Melt Wire Testing,” INL Interoffice Memorandum, October 14, 2011. 